34. Максимов И.В. Геофизические силы и воды океана // Л., $1973.448 \mathrm{c}$.

35. Смирнов Н.П. Долгопериодные ритмические явления в деятельности Гольфстрима. // Изв. Всесоюз. геогр. о-ва. 1965. №5. C.427-437.

36. Максимов И.В., Смирнов Н.П. Изучение причин многолетних изменений в деятельности Гольфстрима // Океанология. 1965. Т.5, вып.3. С.210-221.

37. Muller P.J., Suess F. Productivity, sedimentation rate, and sedimentary organic matter in oceans. 1. Organic carbon preservation // Deep-Sea Research. 1979. V.26, №12A. P.13471362 .

38. Мигулин В.В. Больше внимания солнечно-земной физике // Вестн. АН СССР. 1991. №11. С. 55-62.

39. Федоров К.Н. Этот капризный младенец - Эль-Ниньо! // Природа. 1984. №8. С.65-74.
40. Barber R.T., Clavez F.P. Biological concequences of El Nino // Science. 1983. V.222, №4629. P.1203-1210.

41. Barrentos C.S. El Nino-Southern oscillation episode of 1982-83 // Mariner's Weather Log. 1984. V.28, №2. P.81-84.

42. Картер У.Е., Робертсон Д.С. Исследования Земли с помощью интерферометрии со сверхдлинной базой // В мире науки. 1987. №1. С.16-25.

43. Викторов Б.Н. Влияние центробежной силы вращения Земли на формирование нефтяных и газовых залежей // Нефтяное хозяйство. 1954. №2. С.42-46.

44. Kitchell J.A., Clark D.L. Late cretaceous-paleogene paleogeography and paleocirculation: evidence of north polar upwelling // Palaeogeography, Palaeoclimatology, Palaeoecology. 1982. V.40, №1-3. P.135-136.

45. Опдайк Н.B. Палеоклиматология и дрейф континентов // Дрейф континентов. Горизонтальные движения земной коры. М., 1966. С.159-182.

УДК $551.762 .22(470.45)$

\title{
АНАЛИЗ ИЗУЧЕННОСТИ ОПОРНЫХ РАЗРЕЗОВ КЕЛЛОВЕЯ В НИЖНЕМ ПОВОЛЖЬЕ
}

\author{
В.Ф. Салтыков, В.Б. Сельцер \\ Саратовский государственный университет, \\ геологический факультет \\ E-mail: dekanat@geol.sgu.ru
}

Проведенное сопоставление результатов изучения келловейских отложений в стратотипическом разрезе Малинового оврага, полученных различными исследователями, показало определенную их несопоставимость по объему и качеству биостратиграфической информации. Ее использование при выделении местных стратонов (свит) привело к уменьшению детальности расчленения отложений. Эти обстоятельства обусловливают необходимость нового всестороннего описания данного разреза с подробным анализом как вновь полученных результатов, так и ранее известных сведений на основе уточненного аммонитового стандарта

Analysis of the Knowledge of the Callovian Type Sections from the Volga Region

\section{V.F. Saltykov, V.B. Seltser}

Comparison of results obtained by various authors from Callovian beds of the stratotype section in the Malinovyj gully has shown to be incomparable in the amount and quality of biostratigraphic information. Using this information for recognizing of local strata (suites) has reduced the minuteness of deposit division. This makes new comprehensive description of the section essential as well as thorough analyses of the latest results in combination with the earlier data on the updated ammonite standard.

\section{Введение}

Стратиграфия келловейского яруса в основном базируется на вертикальном распределении зональных аммонитов по разрезу. Меньшую роль при расчленении играют

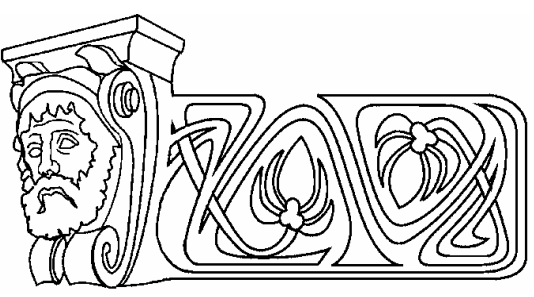

фораминиферы. Следовательно, главное значение приобретает детальность изучения наиболее полных разрезов, где возможно совмещение зональностей по макро- и микрофауне. Для келловея они преимущественно расположены на восточном склоне Приволжской возвышенности, в бассейнах рр.Курдюм и Чардым (к северу от Саратова). Обобщение палеонтологических материалов, собранных в этих обнажениях, послужило каркасом для составления первой стратиграфической схемы келловея Поволжья [1], которая с некоторыми изменениями была включена в унифицированную схему юрских отложений Русской платформы [2]. Список этих обнажений и суммированная фаунистическая характеристика каждого подъяруса приводится в работах $[3,4]$.

Классическим разрезом келловея в Поволжье, изучавшимся в течение десятков лет, считается обнажение в Малиновом овраге (4 км к северо-востоку от с.Хлебновки, на левом берегу Курдюма, в 33 км к северу от Саратова). Овраг приурочен к западной части Хлебновского поднятия на стыке с Корса- 
ковской впадиной, входящих в Саратовские дислокации. Именно полученные здесь материалы послужили основой для выполнения посвитного расчленения келловейских отложений [5-7]. По предложению А.Г. Олферьева выделена курдюмская серия, объединяющая все три подъяруса келловея, включая шесть аммонитовых зон. Она, в свою очередь, делится на три свиты, соответствующие по объему подъярусам (снизу вверх): хлебновскую со стратотипом в данном разрезе; докучаевскую, со стратотипом, расположенным в Нижегородской области, и малиноовражную, стратотип которой также находится в Малиновом овраге. При этом составители нижневолжской (прикаспийской) схемы приняли к сведению результаты работ одних исследователей, не учтя результаты других предшественников, полученные при изучении данного разреза. К тому же для среднего келловея стратотип выбран в другом районе, хотя отложения этого возраста присутствуют в Малиновом овраге, палеонтологическая информация по которым использовалась в схеме саратовских геологов $[1,3,4]$.

Несмотря на существующие различия в биостратиграфических данных, анализ опубликованных материалов позволяет предположить, что степень детальности расчленения по имеющимся фаунистическим сведениям может быть увеличена до уровня не только аммонитовых зон, но и более дробных единиц. Для чего необходимо провести сопоставление результатов работ предшественников и выявить совпадающие и противоречащие моменты. Это касается не только аммонитов, но и фораминифер, которые практически не использованы составителями стратиграфической схемы [5], хотя давно известна стратиграфическая значимость данной группы организмов. При выделении свит важное значение имеют литологическая характеристика и диагностические признаки, которые служат основанием для проведения границ между местными стратонами. Но этому уделено мало внимания. Все сказанное предопределяет необходимость выполнения анализа работ предшественников, чтобы понять степень комплексной обоснованности деления отложений келловея в стратотипическом разрезе Малинового оврага.

\section{Сопоставление биостратиграфических данных} по Малиновому оврагу

Несмотря на частое упоминание в литературе указанного обнажения, по сути, первое его последовательное описание произведено С.Н. Алексеевым и Ю.С. Репиным [8]. Они показали, что нижний келловей представлен глинистыми алевролитами мощностью 23 м, залегающими на косослоистых песках с прослоями глин, содержащих фораминиферы Ammodiscus baticus Dain и отнесенных к среднему бату. Контакт подчеркнут углублениями в песках, заполненными вышележащим глинистым материалом. В нижних 8,5 м разреза были определены аммониты Macrocephalites macrocephalus (Schloth.), Costacadoceras mundum (Sas.). В следующих 4,2 м обнаружены Cadoceras elatmae Nik., Costacadoceras mundum (Sas.), M. macrocephalus (Schloth.). В вышележащих 10 м установлены Cadoceras aff. elatmae Nik., Chamoussetia chamousseti (Orb.), Kepplerites (Gowericeras) gowerianus (Sow.), Sigaloceras $s p$.

Алексеев и Репин отмечали, что в разрезе можно наблюдать три обособленных аммонитовых уровня (снизу вверх): нижний уровень с $M$. macrocephalus (нижние 8,5 м); второй уровень совместного нахождения C. elatmae Nik. и C. mundum (Sas.) (следующие 4,2 м); верхний уровень с Ch. Chamousseti (Orb.) и K. gowerianus (Sow.) (верхние 10 м). Два нижних уровня, по их мнению, соответствуют стандартной зоне macrocephalus, хотя такое заключение принимается с определенной условностью, так как в это время «центр Русской платформы занимает относительно краевое (экотонное) положение в ареале Macrocephalites» [8, с.134]. Недостаточно ясно положение второго уровня, хотя вид C. elatmae (Nik.) представляет собой яркий репер в нижнем келловее, как указывалось В.Г.Камышевой-Елпатьевской и др. [1]. Авторы отмечали: «Однако совместно с C. elatmae (Nik.) в описанном разрезе присутствуют C. mundum (Sas.) и M. macrocephalus (Schloth.), находящиеся и в подстилающих слоях, где $C$. elatmae (Nik.) отсутствует» [8, c.135]. Следовательно, «стратиграфический интервал распространения C. mundum (Sas.) и M. macrocephalus (Schloth.) может отвечать объему единой зоны, а интервал распространения C. elatmae (Nik.) соответствует подзоне» 
[8, с.135]. Третий уровень отвечает зоне gowerianus. Но нижняя граница этой зоны не имеет полной ясности. На ней исчезают $M$. macrocephalus, C. elatmae и Costacadoceras mundum и только через 3 м выше по разрезу появляются Ch. chamousseti (Orb.) и $K$. (G.) gowerianus (Sow.). Обсуждаемые авторами вопросы разделения нижнего келловея будут предметом дискуссий еще на протяжении многих лет.

К среднему келловею отнесены глинистые алевролиты мощностью 5,5 м, в которых установлены единичные Elatmites nikitinoensis Sas., E. submutatus (Nik.), Volgaites $s p$., пелециподы, ростры белемнитов. Вышележащие глинистые алевролиты (3 м) с прослоями известняков включали $E$. nikitinoensis Sas., E. submutatus (Nik.), Pseudocadoceras cf. boreale Buck., Ps. suraense Sas., Proplanulites ex gr. subcuneatus Teiss., Kosmoceras ex gr. jason (Rein.), Volgaites elatmaensis Sas., V. mokschaensis Sas., Rondiceras milaschevici (Nik.), R. tschefkini (Orb.). Этот породный комплекс Алексеев и Репин рассматривали в объеме зоны K. jason стандарта. Верхняя зона Erymnoceras coronatum, по их данным, в разрезе не представлена.

Верхний келловей сложен алевролитами и песчаниками мощностью 9,6 м. В них встречены многочисленные аммониты, характеризующие зону athleta (нижние 1,6 м) с Kosmoceras rowlstonense (Y. et B.) и зону lamberti (верхние 8 м) с Quenstedtoceras lamberti (Sow.), Q. leachi (Sow.), Q. williamsoni Buck. и др.

В этом же году опубликована статья С.В. Мелединой [9], в которой приведены фотоизображения аммонитов, отобранных ею из нижнего келловея в обнажении Малинового оврага. Их наименования несколько отличаются от видов, описанных С.Н. Алексеевым и Ю.С. Репиным. По ее данным разрез сложен глинами с выдержанными горизонтами мергелистых септариевых конкреций, около которых наблюдались крупные (до 250 мм) остатки аммонитов. С.В.Меледина расчленяла разрез по аммонитам следующим образом (снизу вверх): 1) глины мощностью 4,5 м с Macrocephalitidae и Pseudocadoceras cf. mundum (Sas.); 2) глины мощностью 19,5 м с Cadoceras (Paracadocaras) elatmae (Nik.), C. (Bryocadoceras) simula- ns Spath., Ps. mundum (Sas.); 3) глины мощностью 7,5 м с C. (B.) simulans Spath., Ps. mundum (Sas.), Ps. cf. grewingki (Pomp.), Ch. chamousseti (Orb.), K. (G) gowerianus (Sow.), $K$. (K.) galilaei (Opp.), K. (K.) aff. antiguus Spath, Proplanulites cf. majesticus Buck., Choffatia sp., M. (M.) formosus (Sow.); 4) глины мощностью 2 м с $S$. cf. calloviense (Sow.), Chamoussetia sp., которые перекрываются средним келловеем мощностью 1,5 м с Rondiceras milaschevici (Nik.), Indosphinctes (Elatmites) elatmaensis (Sas.), I. (E.) mokschaensis (Sas.), Questedtoceras praelamberti (Douv.).

C.B. Меледина обсуждает стратиграфическое положение аммонитов при сравнении с аммонитовой шкалой Западной Европы, используя также сведения из других разрезов на Русской платформе. Она пришла к следующим выводам, которые отчасти не согласуются со схемой деления келловея, изложенной в работе [10].

1. Глины с $S$. calloviense (Sow.) в полной мере соответствуют одноименной аммонитовой подзоне - верхней части зоны Proplanulites koenigi стандарта. Однако самая верхняя зона нижнего келловея «Sigaloceras» enodatum в Малиновом овраге отсутствует. Меледина, ссылаясь на свою раннюю работу [11], полагала, что вид Kosmoceras enodatum (Nik.) целесообразно относить уже к среднему келловею, как еще в 1885 г. предполагал С.Н.Никитин. Она подчеркивала: «Аналоги самой верхней подзоны стандарта нижнего келловея не устанавливаются на Русской платформе ни в описанном выше, ни в других местонахождениях подъяруса» [9, с.70].

2. Следующие два комплекса аммонитов (слои 2 и 3) соответствуют нижней подзоне зоны Р. koenigi стандарта. Она указывала, что «на Русской платформе выявлен четкий и надежный биостратиграфический репер аналог подзоны Р. koenigi стандарта» [9, с.70].

3. Нижняя зона M. macrocephalus разделяется С.В.Мелединой на две части: верхняя C. elatmae соответствует подзоне M. kamptus стандарта, нижняя с Arcticoceras ishmae подзоне M. macrocephalus, хотя вид $A$. ishmae в разрезе Малинового оврага не обнаружен. Он установлен надежно только в бассейне Печоры. С.В.Меледина отметила, что ввиду недостаточности палеонтологических данных не следует пока слои с M. macrocephalus отделять от зоны C. elatmae. 
В качестве итогового заключения приведем цитату из работы С.В.Мелединой: «Теперь, когда выяснилось значительное соответствие двух комплексов аммонитов в верхней половине нижнекелловейского подъяруса Русской платформы и стандарта, следует признать нецелесообразность сохранения прежней номенклатуры этих подразделений (имеется в виду стратиграфическая схема 1962 г. - В.С. и В.С.). Верхняя часть нижнего келловея на Русской платформе, как и в стандарте, должна обозначаться как зона Sigaloceras calloviense с подзонами Proplanulites koenigi внизу и S. calloviense вверху. Вид-индекс самой верхней подзоны $S$. calloviense и близкие ему виды широко pacпространены на Русской платформе... Видиндекс P. koenigi пока установлен только в Днепровско-Донецкой впадине наряду с другими видами Proplanulites. В Саратовском Поволжье выявлено широкое распространение нижнекелловейских Proplanulites, отсутствие которых в ранее собранных коллекциях специалистов можно объяснить трудностями отбора из глин их крупных раковин. Мною описан близкий к P. koenigi (Sow.) вид P. cf. majesticus Buck» [9, c. 72].

В другой статье С.В. Меледина [12] предложила аммонитовую зональность в келловее Русской платформы в сопоставлении со стандартом Западной Европы. Она несколько отличалась от зональной схемы, принятой в 1962 году. С.В. Меледина отметила: «Наибольшие трудности определения ранга и обозначения отдельных биостратонов и их корреляции со стандартом вызвал нижний подъярус. Это обусловлено весьма противоречивыми сведениями о вертикальном соотношении отдельных родов и видов аммонитов, таких как Macrocephalites, Chamoussetia, Kepplerites, Sigaloceras» [12, c.120]. Автор предложила называть нижнюю зону нижнего келловея - C. elatmae, которая сопоставлялась с подзоной M. kamptus стандарта. Она приводила типовые виды, в том числе и Pseudocadoceras mundum (Sas.), а также полагала, что «...достоверных выходов зоны в более южных районах Европейской части СССР (южнее Саратова - B.C. $u$ B.C.) не известно» [12, с.122]. Отдельные находки Macrocephalites и Cadoceras в Прикаспии «...не могут считаться основанием для установления нижней половины нижнекелловейского подъяруса...» [12, с.122].

Зона Sigaloceras calloviense с подзонами Proplanulites koenigi (внизу) и S. calloviense (вверху) наиболее обоснована находками аммонитов, в том числе и в Поволжье. Автор отмечала: «Во многих районах развития зоны S. calloviense еe верхняя подзона бывает, повидимому, размыта. Иногда она не может быть отделена по аммонитам от нижней подзоны P. koenigi» [12, с. 124].

«Средний келловей на Русской платформе представлен, как правило, в неполном объеме и имеет незначительную мощность (от 0,5 до 18 м)... Соотношение отдельных компонентов в аммонитовых комплексах значительно меняется в разных районах региона. Это отражает, с одной стороны, палеогеографическую и палеонтологическую их специфику, а с другой - что более характерно, - различную полноту объема подъяруса. Часто распределение по вертикали отдельных родов, подродов и видов аммонитов не допускает зональное деление среднего келловея» [12, с.124].

Для верхнего келловея наиболее представительными по разнообразию аммонитов являются разрезы в Саратовском Поволжье.

В монографии, опубликованной через год, С.В. Меледина [13] разрез нижнего келловея в Малиновом овраге наращивала уже вплоть до верхнего подъяруса. Средний келловей с вышеуказанными аммонитами она относила к верхней подзоне Erymnoceras coronatum, полагая, что нижняя подзона приходится на перерыв в осадконакоплении. Этот вывод вступает в противоречие с заключением С.Н. Алексеева и Ю.С. Репина, которые обосновывали противоположное положение данных отложений. С.В. Меледина в свое подтверждение отмечала: «На зону E. coronatum указывают широко распространенные в комплексе Binatisphinctes (Okaites) mosquensis (Fisch.) и единственный экземпляр Quenstedtoceras cf. praelamberti (Douv.)» [13, c.122].

В верхнем подъярусе различаются две зоны. Нижняя из них Peltoceras athleta представлена глинами мощностью 1,7 м с многочисленными экземплярами Kosmoceras (Lobokosmoceras) proniae Teiss., K. (L.) rowlstonense (Y. et B.), K. (Kosmoceras) transitionis 
Nik., K. (K.) duncani (Sow.) и единичными Hecticoceras glyptum Buck., Quenstedtoceras flexicostatum (Phill.). Верхняя зона Q. lamberti представлена глинами с желваками фосфоритов мощностью 4,5 м, обнажающимися в верховьях оврага. В них встречались многочисленные представители рода Quenstedtoceras: Q. lamberti (Sow.), Q. leachi (Sow.), $Q$. henrici (Douv.), Q. flexicostatum (Phill.)., Q. williamsoni (Buck.), Eboraciceras omphaloides (Buck.), Kosmoceras (K.) tidmoorense Ark., $K$. (K.) transitionis Nik., K. (K.) annulatum (Quen.), Properisphinctes bernensis (Lor.), Binatisphinctes (Okaites) cf. mosquensis (Fisch.).

Приведенные С.В.Мелединой видовые описания аммонитов намного превосходят таковые у С.Н.Алексеева и Ю.С.Репина. Кроме того, приведенные данные по одному и тому же разрезу отличаются также разной литологией, некоторым несоответствием мощностей, но главное - различной трактовкой стратиграфического положения среднего келловея.

Примерно в то же время депонирована работа Г.В. Кулевой в соавторстве с коллегами, представившими описание опорного разреза в Малиновом овраге [14]. Данные авторы стремились наиболее полно охарактеризовать вскрываемые отложения. На основании результатов гранулометрического анализа они доказали преимущественно глинистый состав изученных пород. В подошве $(0,4-3$ м) залегают алевриты, выше располагаются алевритовые глины с суммарной мощностью 10,4-13 м. Глинистые минералы представлены гидрослюдой (60\%), смектитом (20\%), каолинитом (20\%). Установлена магнетитильменит-эпидотовая минеральная ассоциация. Эти породы содержат аммониты C. elatmae (Nik.), C. modiolare (Orb.), M. macrocephalus (Schloth.), Pseudocadoceras dorbignyi (Maire), K. (G.) gowerianus (Sow.), Ch. Chamousseti (Orb.). Это сообщество принято считать соответствующим зоне C. elatmae. Фораминиферовый комплекс включает виды Lituotuba nodus Kosyr., Haplo-phragmoides cf. infracalloviensis Dain, Ammo-baculites ex gr. fontinensis Terq.

Выше залегают алевритистые глины мощностью 10 м. Минералогические признаки остаются теми же самыми. Кровля отложений размыта, что подчеркивается сменой окрасок пород выше по разрезу. В них установлены Ch. chamousseti (Orb.), K. (G.) gowerianus (Sow.), редкие C. elatmae (Nik.) и S. calloviense (Sow.) в верхах разреза. Учитывая появление последнего вида, отложения соотносили с одноименной зоной нижнего келловея. Из фораминифер указаны $\mathrm{Am}$. ех gr. fontinensis Terq., Recurvoides sp. Встречены также белемниты и двустворки. Отложения нижнего подъяруса характеризуются в целом обратной магнитной полярностью, но в верхах отмечаются интервалы прямого знака.

Нижняя зона среднего келловея Kosmoceras jason - представлена алевритовыми глинами с прослоями алевритов мощностью 9,5 м. В пелитовой фракции убывают концентрации гидрослюд (40\%), но возрастают содержания смектита (до $30 \%$ ), каолинита (до 25\%), появляется хлорит (до $15 \%$ ). Меняется и состав ассоциации устойчивых минералов - она соответствует циркон-гранатильменит-рутилу с примесью хромита. По палеомагнитным данным, в отложениях преобладает обратная полярность, но в верхах появляется, вероятно, прямая намагниченность. Среди аммонитов наблюдаются Kosmoceras jason (Rein.), K. gulielmii (Sow.), Rondiceras milaschevici (Nik.), Perisphinctes (Elatmites) sp., I. mutatus Traut. Указано несколько видов белемнитов. Состав фораминиферового комплекса разнообразен, с типовыми видами среднего келловея. Кровля зоны размыта, а породы верхней зоны Е. coronatum не установлены.

Верхний келловей в низах разреза сложен известковистыми глинами с прослоями известняков. Минералогические признаки в целом аналогичны среднекелловейским породам. Среди аммонитов обнаружены P. rjasnensis Teiss., K. spinosum (Sow.), K. cf. proniae Teiss., $K$. rowlstonense (Y. et B.), $K$. transitionis Nik., Q. praelamberti Douv., Q. flexicostatum (Phill.), Q. brasili Douv., Q. mariae (Orb.), Q. lamberti (Sow.). Указаны белемниты и двустворки. Состав фораминиферового комплекса обилен и разнообразен, с типовыми видами верхнего келловея. Кулёва, наряду с другими авторами, соотносит отложения мощностью 6 м с зоной Peltoceras athleta. В породах установлена обратная магнитная полярность. 
Верхняя зона Q. lamberti представлена светло-серыми известковистыми глинами мощностью до 5 м в обнажении и 22 м в скважине, которая, однако, не имеет номера и расположение ее является приблизительным. В глинах встречены аммониты Q. lamberti (Sow.), Q. flexicostatum (Phill.), Q. mariae (Orb.), Q. omphaloides (Sow.), Q. henrici Douv., белемниты и двустворки. Состав фораминиферового комплекса очень близок к выделенному из нижней зоны. Палеомагнитная характеристика является не вполне ясной, больше оснований полагать здесь прямую полярность.

Сравнение описаний Г.В.Кулевой с коллегами и С.В.Мелединой при некоторых отличиях показывает их большое сходство, прежде всего по литологии, но они не совпадают по величинам мощностей среднего и верхнего келловея и по наборам характерных аммонитов. С другой стороны, данные Г.В. Кулевой с коллегами подтверждают сведения С.Н. Алексеева и Ю.С. Репина о присутствии зоны K. jason и размыве отложений зоны E. coronatum, что противоречит представлениям С.В.Мелединой.

Фораминиферовые комплексы даются в виде списка, хотя ранее Г.Н. Старцева и Т.Н.Хабарова [15] приводили распределение видов по всему разрезу в Малиновом овраге. Их рисунок лучше характеризует микрофаунистическую зональность в келловее (рисунок), причем сделана попытка сопоставить фораминиферовые комплексы с аммонитовыми зонами, принимая во внимание то положение, что в среднем келловее представлены обе зоны. Распределение фораминифер по разрезу выявило следующие особенности: a) отложения нижнего келловея содержат бедную микрофауну; любопытно, что в ее состав входит вид Reophax scabrosus Starts., который Г.Н. Старцевой $[16,17]$ отнесен к самым низам подъяруса; б) с определенной условностью можно отметить самостоятельные наборы видов микрофауны для отложений, соответствующих каждой аммонитовой зоне, хотя авторы в целом придерживаются традиционной схемы стратификации келловея по фораминиферам [18]; в) сравнение таксономического состава комплексов, изученных в отложениях Малинового оврага и в других разрезах (включая и скважины) Ниж- него Поволжья, выявило его относительную обедненность в породах этого района.

В качестве завершающей работы, посвященной описанию разреза в Малиновом овраге, следует рассмотреть монографию Ю.С.Репина и Н.Х.Рашвана [19]. Ее большая часть отводится описанию и фотоизображению аммонитов. Меньшее место занимают вопросы стратиграфии. Авторы повторяют литологическое описание разреза, приведенное ранее [8], и расширяют список найденных ими аммонитов. Они совершенно не упо минают о результатах исследований Г.В.Кулевой и др. и лишь частично обсуждают данные С.В. Мелединой. Главное же значение их интерпретации сводиться к тому, что они пытаются сопоставить данные по Малиновому оврагу с уточненным аммонитовым стандартом.

Репин и Рашван отмечают полное отсутствие самой нижней зоны нижнего келловея herveyi современного стандарта [20] в районе Мангышлака. Однако в Малиновом овраге она присутствует и сопоставляется с зоной Costacadoceras mundum. При этом найденный в основании разреза в данном обнажении аммонит неудовлетворительной сохранности, определяемый ранее как Macrocephalites, установлен как M. cf. triangularis Spath, который входит в группу древнейших макроцефалитов. В связи с чем авторы соотносят породы мощностью 3,5 м с нижней подзоной Kepplerites (K.) keppleri стандарта. Верхняя подзона в Малиновом овраге (С. elatmae) не имеет достаточно надежного положения, тем не менее они эту подзону сопоставляют с двумя подзонами М. (М.) terebratus и М. (К.) kamptus стандарта.

Выше располагается зона Proplanulites koenigi, в которой выделяется подзона gowerianus, сопоставляемая с нижней одноименной подзоной стандарта. Однако две верхние подзоны стандарта К. (K.) curtilobus и К. (K.) galilaei в разрезе Малинового оврага авторы не могут идентифицировать. Заметим, что С.В. Меледина обнаружила типовой аммонит $K$. (K.) galilaei (Opp.), что заставляет по-иному взглянуть на выводы Ю.С. Репина и Н.Х.Рашвана в данном отношении.

В изучаемом разрезе упомянутые авторы выделяют подзону calloviense в объеме, сопоставимом с объемом одноименной под- 


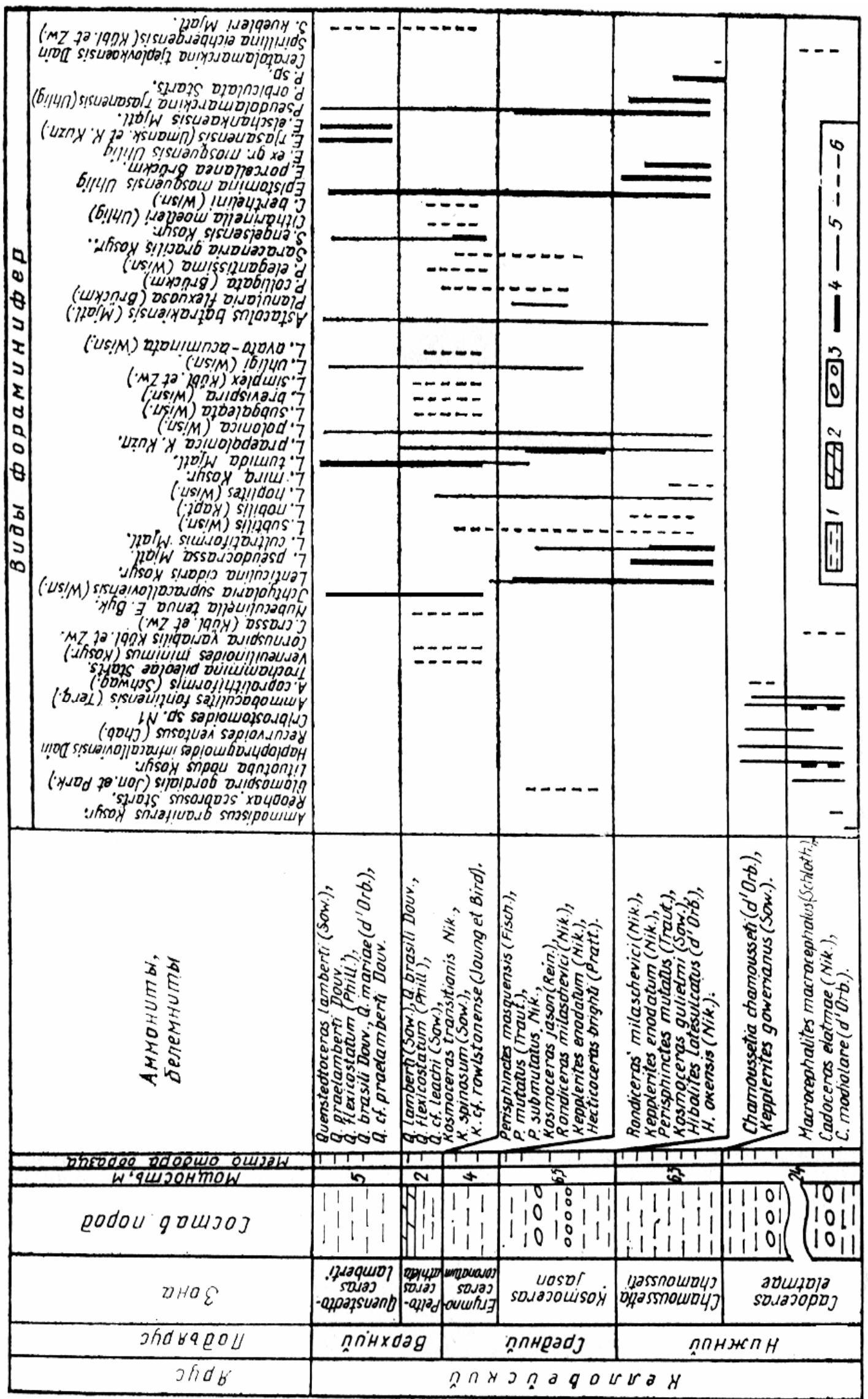


зоны стандарта. Однако выше расположенная подзона enodatum в Малиновом овраге не имеет надежного аммонитового подтверждения. Они подчеркивают: «На Русской платформе до сих пор не выявлен разрез, в котором можно было бы проследить непосредственный переход от нижнего к среднему келловею» [19, с.17]. В рассматриваемом разрезе «выше находок $S$. calloviense выявлен интервал, содержащий как элементы нижнего, так и среднего келловея, что не позволяет однозначно трактовать его возраст. Но здесь отсутствует K. jason, вид-индекс нижней зоны среднего келловея» [19, с.17]. Поэтому Алексеев и Репин считают, что отложения, приходящиеся на интервал мощностью 4,5 м с аммонитами Sigaloceras (Catasigaloceras) planicerclus (Buck.), Indosphinctes (Elatmites) elatmaensis Sas., I. (E.) cf. submutatus (Nik.), Pseudocadoceras petelini (Pomp.), Ps. (Novocadoceras) cf. suraense Sas. в подстилающих известняках и $S$. (C.) enodatum (Nik.), $S$. (C.) planicerclus (Buck.), Kosmoceras (Gulielmites) subnodatum Teiss., K. (G) ex gr. medea Call., K. (G.) lorenzi Repin, Rondiceras milaschevici (Nik.), I. (E.) mokschaensis (Sas.), I. (E.) submutatus (Nik.), I. (I.) mutatus (Traut.) из покрывающих глин, соответствуют объединенным подзонам enodatum нижнего келловея и medea среднего подъяруса. Однако, как и в выше рассмотренном случае, такой подход не согласуется ни с данными С.В. Мелединой, ни с данными Г.В.Кулевой и др. Таким образом, предположение Ю.С. Репина и H.Х. Рашвана о том, что верхняя подзона jason и вся верхняя зона Е. coronatum среднего келловея приходится на перерыв в осадконакоплении, вступает в противоречие или частично с представлениями Г.В. Кулевой и др., или полностью с результатами С.В. Мелединой.

В верхнекелловейских отложениях данные авторы отмечают отсутствие самой нижней подзоны phaeinum, что вполне вероятно. Две последующие подзоны proniae и spinosum зоны Peltoceras athleta и обе подзоны зоны Q. lamberti представлены в рассматриваемом разрезе. Исследователи не обсуждают вопрос мощностей отложений, но приводимые ими величины лишь частично можно сравнивать с данными С.В. Мелединой и Г.В.Кулевой и др.
Столь подробно изложенные материалы по описанию келловея в Малиновом овраге показывают, что сведения, полученные различными исследователями примерно в одно и то же время, кроме монографии Ю.С.Репина и Н.Х. Рашвана [19], не в полной мере согласуются между собой. Это касается и литологии, и величин мощностей, и списка обнаруженных аммонитов, и интерпретации их стратиграфического положения, и следовательно, выделения стратонов. Лишь в монографии Репина и Рашвана отчасти обсуждаются данные С.В. Мелединой, но не упоминаются результаты Г.В.Кулевой и др. А ведь речь идет об описании стратотипического разреза келловея для Русской платформы.

Только в работах [14] и [15] приводятся фораминиферовые комплексы, причем в статье Г.Н. Старцевой, Т.Н. Хабаровой [15] убедительно показана обедненность микрофаунистической характеристики по сравнению с другими районами Поволжья.

Упоминание Г.В. Кулевой и др. о скважине около Малинового оврага нельзя принимать во внимание, так как сведения по ней в работе отсутствуют. Между тем поблизости от оврага расположена скважина 36, пробуренная еще в 1950-е гг., с приличным описанием керна, определениями фораминифер и каротажной диаграммой. Судя по этим данным, мощность отложений составляет: для нижнего келловея - 30 м (184-154 м), для среднего - 26 м (154-128 м), верхнего - 4 м (128-124 м). Поэтому трудно понять величину мощности последнего подъяруса в 22 м, приводимую в работе Г.В.Кулевой и др. Данные по скважине 36 лучше согласуются с результатами других исследователей. В то же время в материалах исследования В.П.Николаевой (1968 г.) приводятся сведения о мощностях верхнего келловея, достигающих величин $45 \mathrm{M}$.

Ни в одном из описаний не обращено внимание на то обстоятельство, что Малиновый овраг приурочен к зоне флексуры, где породы залегают под разными углами падения. Таким образом, осталось неясным, о каких мощностях идет речь - истинных или видимых. Все исследователи рисуют сводный разрез и не показывают, как же распределены конкретные обнажения по оврагу. По нашим данным, там действительно разрез 
является непрерывным без пропусков наблюдений, т.е. одни слои непосредственно залегают на нижележащих породах. Однако между выделяемыми подъярусами всеми исследователями отмечались следы перерывов. Кроме того, в овраге не установлена верхняя часть верхнего келловея.

В других местах Нижнего Поволжья известны обнажения, в которых вскрываются лишь части полного разреза келловея. Следовательно, их биостратиграфическая ценность невелика. Материалы по ним обобщены в работе [4]. Но в последние годы были обнаружены новые обнажения, из которых получена новая информация. В.Б.Сельцер [21], описывая нижнекелловейские отложения в Елшанском разрезе (около Саратова), нашел аммониты Kepplerites cf. keppleri (Opp.), Cadoceras cf. bodylevskii Freb. и Costacadoceras sp. Первый вид характеризует низы зоны herveyi стандарта, что дает основание считать ее присутствие в разрезе Малинового оврага. Следует обратить внимание на новое местонахождение фауны, уникальной по своей сохранности и стратиграфической значимости, в окрестностях пос.Дубки [22]. В публикации В.В.Митты [23] обсуждается палеонтологическая обоснованность верхней границы келловея в бассейне Волги. Автор отмечает, что в окрестностях Саратова пограничные отложения келловея и оксфорда представлены прекрасным разрезом (пос. Дубки), где присутствует фаунистический горизонт paucicostatum (верхи зоны lamberti). Ранее в диссертационных материалах В.П.Николаевой также указывалось на непрерывность разреза между келловеем и оксфордом в некоторых скважинах в районе Саратова.

\section{Заключение}

Изложенные сведения об изученности стратотипического разреза в Малиновом овраге можно суммировать в следующих выводах.

1. Проведенный анализ результатов изучения одного и того же разреза различными исследователями, выполненный в течение 1980-90-х гг., выявил как фаунистическую обоснованность деления келловея на уровне подъярусов, что было известно давно, так и неодинаковые наборы аммонитов, особенно на уровне зон, подзон и фаунистических горизонтов. Наибольшие противоречия выражены в трех моментах. Первый момент - осталась невыясненной полнота разреза нижнего келловея, учитывая находки В.Б. Сельцера к югу от рассматриваемого оврага. Аналогично можно сказать и об объеме верхнего подъяруса. Второй - существуют неопределенности и при проведении границ между зонами. Третий - приводится противоречивая биостратиграфическая информация по поводу присутствия или отсутствия отложений какой-либо одной из аммонитовых зон среднего келловея.

2. Выполненные исследования базировались на частично устаревшей аммонитовой шкале, исключением является монография [19]. В настоящее время для Западной Европы принята новая более дробная шкала [24, 25]. Аналогичные работы проведены и для центра Русской платформы [26, 27]. Анализируя изображения аммонитов В.Г. Камышевой-Елпатьевской и др. [1], собранных в Малиновом овраге, Дж. Калломон и Дж. Райт высказали предположение, что вид Cadoceras elatmae Nik., неизвестный в Западной Европе, и формы Kepplerites gowerianus (Sow.) происходят из тех же окрестностей и той же зоны и могут быть сопоставлены с подзоной koenigi [24].

Следовательно, необходимо дополнительное изучение данного разреза. Новый подход продемонстрирован в работах [27, 28], где проанализировано стратиграфическое положение ранее известных и вновь встреченных видов аммонитов именно с позиций обновленного аммонитового стандарта [20].

3. Если по аммонитам получена хотя и несовпадающая по качеству, но ценная информация, то по другим группам фоссилий, в частности по фораминиферам, кроме статьи [15], данные практически отсутствуют. Стратиграфическая значимость микрофауны при расчленении отложений общеизвестна, и она убедительно показана Г.Н.Старцевой и Т.Н.Хабаровой как для Малинового оврага, так и для других районов Поволжья.

4. Литологическая характеристика стратонов, выделенных по материалам из Малинового оврага, основывается, видимо, на визуальных наблюдениях. Только в работе 
Г.В.Кулевой и др. [14] приводятся результаты лабораторных исследований. Однако эти сведения оказались не полностью востребованными, что отразилось на комплексности обоснования при выделении свит [5], снижая тем самым значимость данного разреза, призванного служить эталоном для последующего сравнения.

\section{Библиографический список}

1. Камышева-Елпатьевская В.Г., Николаева В.П., Троичкая E.A. Стратиграфия юрских отложений Саратовского Правобережья по аммонитам // Тр. ВНИГРИ. 1959. Вып.137. С.3-265.

2. Сазонов Н.T. Унифицированная схема стратиграфии юрских отложений Русской платформы (проект) // Тр. ВНИГНИ. 1961. Вып.29, т.2. С.5-46.

3. Камышева-Елпатьевская В.Г., Николаева В.П., Троицкая Е.А., Хабарова T.Н. Келловей юго-востока Русской платформы и его фауна // Вопр. стратиграфии верхней юры. М., 1974. С.20-28.

4. Николаева В.П., Троиикая Е.А. Фаунистическая характеристика келловея Саратовского и Волгоградского Поволжья // Вопр. стратиграфии и палеонтологии. Саратов, 1975. Вып.1. С.42-54.

5. Левина В.И., Прохорова Н.П. Местные стратиграфические подразделения нижней и средней юры Прикаспийского региона // Недра Поволжья и Прикаспия. 2002. Вып.29. С.6-13.

6. Объяснительная записка к унифицированной стратиграфической схеме юрских отложений Русской платформы. СПб., 1993. 72 с.

7. Олферьев А.Г. Юрские отложения востока Русской платформы // Вопр. совершенствования стратиграфической основы фанерозойских отложений нефтегазоносных регионов России. СПб., 1997. С.95-107.

8. Алексеев С.Н., Репин Ю.С. Новые данные по келловейским отложениям Малинового оврага (Саратовское Поволжье) // Юрские отложения Русской платформы. Л., 1986. C.130-137.

9. Меледина С.В. Зональное деление нижнего келловея Русской платформы // Изв. АН СССР. Сер. геол. 1986(а). №7. C.66-74.

10. Зоны юрской системы в СССР // Тр. МСК. 1982. Т.10. $192 \mathrm{c}$.

11. Меледина С.В. Неправомерность использования вида Kosmoceras enodatum Nikitin в качестве подзонального индекса нижнего келловея // Геология и геофизика. 1984. №5. C.55-60.

12. Меледина С.В. Зональное деление келловея Русской платформы // Юрские отложения Русской платформы. Л., 1986(б). C.119-129.
13. Меледина С.В. Аммониты и зональная стратиграфия келловея суббореальных районов СССР // Тр. ИГГ СО АН СССР. 1987. Вып.691. 184 с.

14. Кулева Г.В., Троицкая Е.А., Букина Т.Ф. и др. Опорный разрез келловейского яруса оврага Малиновый. Саратов, 1988. 55 с. Деп. в ВИНИТИ 10.06.88 г. № 4605 - В88.

15. Стариева Г.Н., Хабарова Т.Н. УльяновскоСаратовский прогиб и северо-западная часть Прикаспийской впадины // Биостратиграфия верхнеюрских отложений по фораминиферам. Вильнюс, 1982. С.50-61.

16. Стариева Г.Н. Детальное расчленение верхнеюрских отложений Среднего Поволжья по данным изучения фораминифер // Юрские отложения Русской платформы. Л., 1986. C.30-40.

17. Стариева Г.Н., Козлова В.И. Новые виды фораминифер из нижнего келловея бассейна р. Инсар // Вопр. геологии Южн. Урала и Поволжья. Саратов, 1972. Вып.8, ч.1. C.122-128.

18. Григялис А.А., Кузнецова К.И. Стратиграфическая шкала верхней юры СССР по фораминиферам // Изв. АН СССР. Сер. геол. 1987. №5. С.26-37.

19. Репин Ю.С., Рашван Н.Х. Келловейские аммониты Саратовского Поволжья и Мангышлака. СПб., 1996. 256 с.

20. Biostratigraphie du Jurassique Ouest-Europeen et Mediterraneen. Zonations paralleles et distribution des invertebres et microfossiles / Coord. Cariou E., Hantzperque P. // Bull. Centre Rech. ELF Explor. Prod. 1997. Mem.17. 440 p.

21. Сельцер В.Б. Нижняя граница келловейского яруса на территории Нижнего Поволжья // Проблемы геологии Европейской России: Тез докл. Всерос. науч. конф. Саратов, 29-31 окт. 2002 г. Саратов, 2002. C.45-46.

22. Сельцер В.Б. Новое местонахождение келловейнижнеоксфордской аммонитовой фауны на территории Саратовского Поволжья // Проблемы геоэкологии Саратова и области. Саратов, 1999. Вып.3. С.102-108.

23. Митта В.В. О пограничных отложениях келловея и оксфорда бассейна Волги // Новости из Геол. музея им. В.И.Вернадского. 2003. №11. $21 \mathrm{c.}$

24. Callomon J.H., Wright J.K. Cardioceratid and Kosmoceratid ammonites from the Callovian of Yorkshire // Palaeontology. 1989. V.32. P.799-836.

25. Callomon J.H., Dietl G., Niederhofer H.J. On the true stratigraphic position of Macrocephalites macrocephalus (Schlotheim, 1813) and the nomenclature of the standart Middle Jurassic «macrocephalus zone» // Stuttgart. Beitr. Naturk. 1992. Ser.B. №185. P.1-65.

26. Гуляев Д.Б. Инфразональная аммонитовая шкала верхнего бата - нижнего келловея Центральной России // Стратиграфия. Геол. корреляция. 2001. Т.9, №1. С.68-96.

27. Митта В.В. О проблемах биостратиграфии средней юры Европейской России // Недра Поволжья и Прикаспия. 2004. Вып.39. С.28-33.

28. Киселев Д.Н. Зоны, подзоны и биогоризонты среднего келловея Центральной России // Тр. естественно-географ. фак. Яросл. гос. пед. ун-та им. К.Д.Ушинского. 2001. Спец. вып. 1.38 с. 